\title{
EXPLORING THE MEDIATING EFFECTS BETWEEN TRANSFORMATIONAL LEADERSHIP AND ORGANIZATIONAL PERFORMANCE
}

\section{ABSTRACT:}

Purpose.- This paper studies the possible mediating mechanisms (HRM, learning and innovation) that could exist in the relationship between transformational leadership and organizational performance. This topic has been studied only by a few group of researches and these researchers have not analysed all these concepts jointly.

Design/Methodology/Approach.- This research explores these relationships using Partial Least Squares with data of 200 Spanish industrial companies. Analysing the mentioned relationships in the Spanish context has been done by few researchers before.

Findings.- The study reveals that the adoption of transformational leadership styles improve performance when specific systems of HRM practices, learning and innovation are developed in an organization.

Originality/Value.- This study, therefore, contributes to the understanding of the link between transformational leaders and performance by proposing a model in which it is evinced that this leadership style produce synergies between HRM, learning and innovation, affecting as a last resort performance.

Keywords- Transformational Leadership; Human Resource Management Practices; Exploitation; Exploration; Learning; Innovation; Performance.

JEL Codes.- M10, M12 


\section{Introduction}

Transformational leadership can be described as a style of leadership that promotes the collective interest of employees, helping them to get collective goals (García-Morales et al., 2012). Moreover, transformational leaders inspire their followers, enhancing employees' knowledge and learning to get them to be innovative in problem-solving tools (GarcíaMorales et al., 2012). Transformational leaders dispose of charisma, intellectual stimulation and inspire their employees, enhance communication, trust and the sharing of knowledge (Senge, 1990, Bass and Avolio, 2000). These leaders are key in stimulating a climate that encourage organizational learning (Narver and Slater, 1990).

That is why this leadership style is awaited to promote higher performance than other leadership styles, such as the transactional or the laissez-faire ones (Bass and Avolio, 2000). Although evidence demonstrates that transformational managers have influence over performance, it becomes of special interest through which processes this fact occurs (GarcíaMorales et al., 2008). In this sense, although several studies have analysed the influence of transformational leadership on performance through other variables, such as culture or competitive strategies (Menguc et al., 2007), the existence of these kind of analyses is still limited. In fact, authors such as García-Morales et al. (2008) or García-Morales et al. (2012) advocate that research could investigate other concepts that mediate in the relationship between transformational leadership and performance.

However, this relationship between transformational leadership and organizational performance is even more important in today environments, where companies must be innovative in order to achieve competitive advantages that enable them to increase their results (Aragón-Correa et al., 2007, Donate and Sánchez de Pablo, 2015). In this case, managers must be able to influence their employees to become involved in innovation processes, acquiring new knowledge that allows companies to launch new products to the market (Andriopoulos and Lewis, 2010). In this regard, transformational leadership and human resources practices have been considered by recent literature as triggers for improving 
learning competences and innovation (Afacan Findıklı et al., 2015). Besides, Gumusluoglu and Ilsev (2009) affirm that the processes that mediate in the relationship between transformational leadership and innovation should be examined. As well, Heffernan et al. (2016) point out there is a need of research concerning the variables that mediate between human resources practices systems and performance.

Moreover, authors highlight the crucial role of knowledge management in enabling companies to obtain information from their environments and their stakeholders and transform it into knowledge. Consequently, in order to innovate, companies need to create new and different learning knowledge for developing innovative products, services, or new methods of production. This learning could be split into two learning capabilities: exploitation and exploration (Alpkan et al., 2012). Exploitation implies the refinement of current organizational process, using current competences in order to be more efficient, improve production procedures and look for relatively certain benefits. However, exploration focuses on the research and development of new competences for discovering of new possibilities, varying product lines and attaining an uncertain outcome. Thus, it becomes essential not only to exploit the existing products or services, but also to explore the chances to carry out new ones.

Furthermore, the relationship between learning and innovation is complex and should be broadly studied under other perspectives. Thus, in order to fill the literature gaps that have been introduced, the impact of transformational leadership on performance is examined, by using the mediating practices of human resources management (HRM), learning and innovation.

Concretely, this research takes into account the gaps reflected by previous literature and carry out four important contributions. First, this study contributes to the understanding that transformational leadership enhances a system composed by a series of practices regarding human resources that mediate the relationship between learning capabilities and performance, through incremental and radical innovation. Second, these results show that learning 
capabilities promote product innovations. Finally, the paper suggests that learning and innovation mediate the relationship between HRM and performance.

Finally, few empirical studies have partially analysed these relationships in the Spanish industry (Aragón-Correa et al., 2007, García-Morales et al., 2012). Therefore, it seems to be a definite need for conducting an empirical link between transformational leadership and organizational performance, taking into account the probable mediation of HRM, learning and innovation.

The paper is organized as follows. In the next section, a literature review as a base for this study is developed, together with the hypotheses statement. Afterwards, the methodology part is explained. Finally, the results are discussed, followed by the limitations of the study and suggestions for future research lines.

\section{Theoretical framework}

\subsection{LHRM practices system and organizational learning}

Organizational learning has become a dynamic research subject-matter, since it is seen as a key strategic activity for companies' growth and sustainability over time (Hung et al., 2011). In this sense, one of the most broadly typologies used on learning studies is the classification of March (1991), that differentiates between exploration and exploitation strategies. March (1991) wrote that exploitation "includes such things as refinement, choice, production, efficiency, selection, implementation, execution". In contrast, exploration "includes things captured by terms such as search, variation, risk taking, experimentation, play, flexibility, discovery, innovation" (March, 1991).

Nevertheless, both types of learning strategies have been criticized in several ways. Thus, exploration has not been considered to generate a deep knowledge in an organization (Kyriakopoulos and Moorman, 2004). Besides, exploitation has been reprehended to bear the impacts of obsolescence along time (Popadiuk, 2012). In fact, March (1991) argued that every organization requires from both types of learning. Finally, both of them may constitute 
in an organization what has been called ambidexterity. Ambidexterity can be defined as an organization's ability to achieve different goals at the same time, not only exploit current competencies, but also explore new opportunities with balanced dexterity (Cingöz and Akdoğan, 2013).

In this line, exploratory and exploitative learning are sustained by HRM practices in order to favour an ambidextrous strategy (Afacan Findıklı et al., 2015). In this regard and in accordance with Turner et al. (2013), intellectual resources at different levels (individual, group or organization) promotes ambidexterity. Concretely, the HRM practices system proposed in this paper is composed by the main HRM practices: selection, training, performance appraisal and compensation, inspired on prior literature but not exactly the same, such as the High Performance Work Systems (HPWS) analysed empirically by Huselid (1995), and founded on the idea that HRM practices applied together promote learning and innovation. The term LHRM has been included in this research since, although HPWS or other similar terms are already utilized in literature, any of these proposed systems covers just the four practices collected here developed in a concrete way, which is the key why this specific system is proposed. The way these practices should be encouraged is explained below and also by their items (see the Appendix section). It is also interesting that authors such as Obeidat et al. (2016) have opted for an AMO framework model, where employee performance may increase if three dimensions (ability, motivation, opportunity) are welldeveloped: skill-enhancing HR practices (e.g. rigorous selection and extensive training), motivation-enhancing HR practices (e.g. performance appraisal, compensation) and opportunity-enhancing HR practices (e.g. job design, work teams, employee involvement). However, for instance, Huselid (1995) makes reference to HPWS, referring to several connected HR practices that may enhance employees' and firm performance through improving employees' learning, motivation and innovation. Thus, it is suggested a LHRM practices system that do not cover the opportunity-enhancing HR practices, understanding they are a consequence of the two-dimensional framework presented (skill-enhancing and 
motivation-enhancing practices), that could also be expressed by the enhancement of learning and innovation in a company, as other researches have previously suggested with other concepts. In fact, Ahmad and Allen (2015) in their research about high-performance HR practices include between them for instance career breaks or the sharing with employees of strategic information, what drives finally in their research to less absenteeism or quite rates. In any case, what seems to be clear is that transformational leaders have potential to increase employees' perceptions through knowledge management processes and by enhancing communication processes.

In this regard, one factor that is proposed to influence the existence of these practices may be personnel selection. Concretely, the selection processes should be carried out through a variety of methods to identify the knowledge and skills of the potential employees that are aligned with the organizational philosophy (Ahmad and Schroeder, 2002). Following these authors, teamwork, problem-solving aptitudes, enterprise and the search of improvement should be highly considered in selection processes. Specifically, Wang and Noe (2010) argued that selection and performance appraisal processes trigger an original knowledge in employees that may lead to explorative consecutions.

Likewise, organizations should promote managers to enhance their abilities and competences through continuous learning and training needed for specific jobs. Concerning training, an extensive training contributes to enhance knowledge capabilities, abilities and skills of employees (Barba-Aragón et al., 2014), favouring decisions making as well as liability assumptions in their work. Similarly, Felstead et al. (2010) affirmed that the achievement of exploration competences is due partly to employees' training. This is due partly to a high autonomy level, to a raised task identity (Felstead et al., 2010), as well as to the fact that these employees present self-control and diligence. In this line, these authors argued that more training carries more skills' enhancement, what can be a trigger of improving their works by involving employees in decision-making processes.

Thirdly, in regard with performance appraisal, Soltani et al. (2003) concluded that formal 
performance appraisals should be made frequently, at least one a year, and their results could be used subsequently for training planning and career development. Moreover, Afacan Findiklı et al. (2015) suggest that performance appraisals based on organization or teamwork performance lead to a higher level of exploitation on behalf of employees. Additionally, several authors, such as Felstead et al. (2010) concluded that learning competences are promoted when employees take part in planning and checking the quality of their works, such as with the implementation of performance appraisals systems.

Finally, compensation has been revealed to dispose of a strong influence on job satisfaction, motivation and turnover intention (Pooja et al., 2013). In this regard, to use compensation packages that reward employees' efforts, as well as benefits participation (PoChien and Shyh-Jer, 2011) may achieve that employees feel that their efforts are rewarded and, as a consequence, feel more identified with their organization, being motivated to learn continuously.

Therefore, several HRM practices, such as selection, training, performance appraisal and compensation practices, could foster several employees' behaviours that encourage learning Thus, this LHRM system of practices will foster both exploration and exploitation. Therefore, the following hypotheses could be put forward:

$H_{1 a}:$ LHRM has a positive influence on exploitation.

$H_{1 b}$ : LHRM has a positive influence on exploration.

\subsection{Learning and incremental and radical innovation}

A considered body of academic contributions linking learning to innovation has been published (Afacan Findıklı et al., 2015), since many scholars consider that knowledge is the pillar of innovations success (Donate and Sánchez de Pablo, 2015). For example, GarcíaMorales et al. (2012) affirm that when innovation gets a deep level, the learning requested for it is greater.

Notwithstanding, García-Morales et al. (2012) or Jiménez-Jiménez and Sanz-Valle (2011) 
examine the relationship between organizational learning and innovation in a general way, without concreting the types of innovation neither the learning competences. Consequently, deeper research separating the types of learning competences and innovation is needed. As a matter of fact, along history, several types of product innovation have been defined, arriving finally to the nowadays more accepted classification of innovation, dividing it into "incremental innovation" and "radical innovation" respectively (Lu and Chen, 2010). On one hand, incremental innovation is the innovation in which companies utilizes their current resources and capabilities to offer enhancements in the targeted field (Tontini and Picolo, 2014). Its main peculiarity is the fact that it enables continued and perpetual growth with a low risk. On the other hand, radical innovation refers to the innovations that rupture with firms' current practices and knowledge, offering completely new outputs (Baker et al., 2014).

Thus, innovation is also expected to be developed by both exploitation and exploration knowledge in an organization (Popadiuk, 2012). By definition, and following Popadiuk (2012), incremental innovations are related to exploitation, designed on the basis of the existing knowledge in an organization. That is, exploitation tries to adapt existing technologies with the needs and preferences of customers (Cingöz and Akdoğan, 2013). Therefore, a responsive orientation is required, due to the fact that incremental innovations are identified with the understood and satisfaction of the expressed needs of customers (Alpkan et al., 2012). In this sense, firms with a strong skill-base are thought to be more flexible, responsive and open to challenges, and in consequence, more opened to embrace innovation (D'Este et al., 2014). In fact, Santangelo and Pini (2011) suggest a positive relationship between employees' abilities and continuous learning and improvements in existing products and processes.

Furthermore, this kind of orientation provides incremental innovations, since adaptations or incremental changes into products and services are developed, with the aim of satisfying the existing customers' needs and preferences (Alpkan et al., 2012). Thus:

$H_{2 a}$ : Exploitation is positively related to incremental innovation. 
In contrast with incremental innovation, radical innovation is related to exploration, due to the fact that exploration is linked to risk taking, search, experimentation and discovery (Cingöz and Akdoğan, 2013). This, in turn, requires the exploration of different technology, since companies are no longer able to carry out radical innovation based solely on their own knowledge. In this sense, the development of new technologies is essential for exploration, taking into account that flexibility and experimentation are very important for this development (Cingöz and Akdoğan, 2013). Thereby, a proactive orientation is needed, since radical innovations attempt to discover and satisfy latent or emerging needs of customers (Alpkan et al., 2012).

In this regard, according to D'Este et al. (2014), high-skilled employees are expected to be equipped with professional capabilities and competences that contribute to develop new ways to create products or services, independently from other barriers to innovation that could emerge, such as financial constraints or market uncertainties. Related to this, investments in skills of employees complement innovation and its results. In fact, HR function should encourage a continuous flow of competences within and out of the organization, trying to develop new competences for job positions and developing new abilities that expand a learning attitude inside the organization (Wallo et al., 2016). Thus, exploration provides knowledge that is useful for completely new products and services, that is, radical changes (Alpkan et al., 2012). These ideas have not received much empirical attention until recently. Consequently, it is proposed that:

$H_{2 b}$ : Exploration is positively related to radical innovation.

\subsection{Innovation and performance}

Innovation has been considered as one of the most important determinants of firm performance (McKinley et al., 2014). Nevertheless, the connection between innovation and performance has not been tested sufficiently. There are some researches that confirm 
theoretically the link between innovation and learning, such as the one of Zahra et al. (2000). Moreover, there are empirical studies that sustain this relationship, such as the one of GarcíaMorales et al. (2012).

Notwithstanding, according to Arnold et al. (2011), when the goal is the acquisition of new clients, radical innovations must be encouraged, while when the organization wants to be focused on the retention of its clients, continuous improvement activities related to products are more convenient, that is, incremental innovation. However, following Shahin et al. (2017), both types of innovation may increase performance; the first one through the acquisition of new technological knowledge; the second one through the repetition of existing abilities and technology. In this line, Luca and Atuahene-Gima (2007) suggest that, e.g., a depth knowledge of existing and new markets provide firms with incremental and radical innovation that promote firm's performance.

Specifically, radical innovations imply that an organization is the first to adopt an innovation and, as a consequence of this fact, create isolation mechanisms, which provide organizations with higher benefits and incomes. At the same time, imitations are more difficult to carry out, enabling organizations to maintain competitive advantages and increase performance (GarcíaMorales et al., 2012). In this regard, organizational learning capabilities, such as exploration, has a significant impact on radical innovation, what, in turn, has a strong association with firm performance (Murat Ar and Baki, 2011).

Anyway, both types are important triggers to enhance proper performance by means of innovative ideas and actions. In fact, firms that carry out both incremental and radical innovations, are provided with better results (Tontini and Picolo, 2014, Baker et al., 2014). Specifically, several studies have examined the relationship between incremental innovations and performance, concluding that this type of innovation influences positively customers' satisfaction. Others have analysed how radical innovations motivate stronger key results (Baker et al., 2014).

As a consequence, the following hypotheses are proposed: 
$H_{3 a}$ : Incremental innovation influences positively organizational performance.

$H_{3 b}$ : Radical innovation influences positively organizational performance.

\subsection{Leadership in learning organizations}

Leadership implies to continuously motivate and encourage own people and act as a reference model for behaviour and performance, demonstrating ability to adapt the course of the organization in relation to an external environment that changes continuously (Menguc et al., 2007). That is, leaders have to take their organizations into the future by implementing strategies that lead them towards more favourable outcomes. Concretely, from the different types of leadership that exist, transformational leadership strives to align the values and goals of employees with those of the organization by influencing or altering their values, beliefs and attitudes through internalization or identification (Menguc et al., 2007). That occurs due to the fact that transformational leaders facilitate a clear division of responsibilities and competences, in order to face external changes and improve performance (García-Morales et al., 2008).

In fact, Hoon Song et al. (2012) concluded that a transformational leadership, including in it influence, motivation, intellectual stimulus and individualized consideration are necessary for the attainment of a major performance, in which the creation and development of knowledge act worthy.

That is, transformational leaders are characterized by a series of features, such as ambition, motivation, honesty, integrity, business knowledge, self-confidence, cognitive abilities and charisma, which influence behaviours in an organization (Calvo-Mora et al., 2014). Thereby, this leadership style may stimulate organizational results, thanks to the commitment of these leaders to learn, be adapted to the environment and initiate changes in the organization, by creating synergies (García-Morales et al., 2008).

This leadership is even more important in organizations that pursue learning targets. For example, recent studies have attired attention to the fact that organizations are more and more 
attracted by programmes focused on learning how to increase transformational skills and abilities in leaders (Goldman et al., 2013). For instance, and according to Menguc et al. (2007), transformational leadership style allows organizations to learn through experience, exploration and communication. In this sense, transformational leaders entail a deeper acceptance of the mission and objectives of an organization, fostering teamwork and training (García-Morales et al., 2012). In this line, since several scholars have concluded that a synergy among HRM practices is a key element in order to achieve competitive advantages in an organization, it is key that leaders promote them. In fact, Vermeeren et al. (2014) conclude that a stimulating and inspiring leadership style influences positively the implementation of HR practices and the amount of them that will be used. These practices include comprehensive selection processes, extensive training, incentives and performance appraisal management. This system of practices, aligned with a transformational leadership style followed by managers, may boost organizational performance (Lertxundi and Landeta, 2011) through learning and innovation, due to the fact that transformational leaders try to appeal to know-how and learning by creating an adequate climate among employees, as well as through the intellectual stimulation and a personalized attention, generating creativity and stimulating problem-solving decisions (García-Morales et al., 2008).

For all these reasons, it could be expected that:

$H_{4}:$ LHRM mediates the relationship between transformational leadership and organizational performance.

\section{Methodology}

\subsection{Population and Sample}

The population used in this study includes Spanish manufacturing organizations with 50 to 500 employees from the SABI (Iberian Balance Analysis System) database, which contains the largest population of Spanish firms. 
The information was collected with a structured questionnaire via a webpage designed for this purpose. In order to eliminate the possibility of bias, multiple informants from each company were used, enhancing the validity of the research findings. The research focus was directed to four managers at each company: quality, production, innovation and human resource managers. The four managers answered the questions related to leadership and performance, while the human resource one replied the inquiries allied to the LHRM system. Meanwhile the innovation manager was in charge of answering the questions related to learning competences and innovation. The answers to the surveys comprehend the response of the managers to the surveys and, although this is partially a limitation, many studies have also followed this proceeding (Abdul-Halim et al., 2016, Heffernan et al., 2016). Nonetheless, it will be remarked as a limitation of the study in the Conclusions section of the paper. 200 questionnaires were collected. The characteristics of the final sample are summarized in Table 1.

Table 1: Sample Characteristics.

\begin{tabular}{|c|c|c|c|c|c|}
\hline \multicolumn{2}{|l|}{ Activity Sectors } & \multicolumn{2}{|c|}{ Sales Volume (mill. €) } & \multicolumn{2}{|c|}{$\begin{array}{l}\text { Number of } \\
\text { employees }\end{array}$} \\
\hline Manufacture of textiles & $4.98 \%$ & $<10$ & $31.0 \%$ & $55-99$ & $45.0 \%$ \\
\hline Manufacture of leather and related products & $17.41 \%$ & $10-50$ & $43.5 \%$ & $100-250$ & $30.5 \%$ \\
\hline Manufacture of paper and paper products & $1.00 \%$ & $50-100$ & $14.0 \%$ & $250-500$ & $24.5 \%$ \\
\hline Printing and reproduction of recorded media & $3.48 \%$ & $>100$ & $11.5 \%$ & & \\
\hline Manufacture of chemicals and chemical products & $3.98 \%$ & & & & \\
\hline $\begin{array}{l}\text { Manufacture of basic pharmaceutical products and } \\
\text { pharmaceutical preparations }\end{array}$ & $1.49 \%$ & & & & \\
\hline Manufacture of rubber and plastic products & $9.45 \%$ & & & & \\
\hline Metal mechanic & $19.40 \%$ & & & & \\
\hline Manufacture of electrical equipment & $4.48 \%$ & & & & \\
\hline Manufacture of furniture & $27.86 \%$ & & & & \\
\hline Other manufacturing & $6.47 \%$ & & & & \\
\hline
\end{tabular}

\subsection{Measures}

The design of the questionnaire was based on the discussion of the literature. In the research model, all variables correspond to first-order factors with multi-item scales using a five-point Likert scale (1="Strongly disagree"; 5="Strongly agree") for managerial 
perceptions.

\section{Transformational leadership:}

As defined before, transformational leaders make the collective goals transcend the individual ones. In this sense, the features that define the transformational leadership are very similar to the ones described by the EFQM Model (EFQM, 2013). Moreover, since Eskildsen (1998) argues that the information estimated in the EFQM Model is appropriate in order to develop measurement scales, 11 items for measuring all the enablers of the model were used. These items (see Appendix) were extracted from the subcriteria that form the enabler Leadership of the Model, being this construct processed as a reflective construct composed by three second-order constructs (stakeholders, cooperation and improvements) (Bass and Steidlmeier, 1999, Hallinger, 2003, Jung and Sosik, 2002) that were also processed as reflective.

\section{LHRM system of practices:}

For this construct, 12 items (see Appendix) were selected from literature review based on the works of several authors (Huselid, 1995, Bowen and Ostroff, 2004) for covering four HRM areas: selection, training, performance appraisal and compensation. Each measure on HR practices has been processed using four items for each one, improving so content validity, and building four second-order constructs (one for each LHRM practice). Since this construct may be considered as a whole, it was computed as reflective (the second-order constructs and the first-order one).

\section{Exploitation and exploration:}

To measure these two constructs, 5 items for each one of the variables were used (see Appendix). These items were collected from the study of Jansen et al. (2006). Both constructs were considered as reflective, following the same methodology as the authors from whom items were collected. 
Incremental and Radical innovations:

In this research, incremental and radical innovations were measured using 7 items for each one of them (see Appendix). These items were collected from the study of Jansen et al. (2006). Both constructs were considered as reflective, in accordance with Jansen et al. (2006).

\section{Organizational performance:}

For the study of performance it has been applied the development of the different criteria proposed by the EFQM Model to carry out its results' evaluation (EFQM, 2013), since Eskildsen (1998) concludes that the information estimated in the EFQM Model is appropriate in order to develop measurement scales. With this idea, 4 items that make reference to organizational results (Key results in EFQM) were used (see Appendix). It was computed as a reflective construct, such us other studies have done (Santos-Vijande and Álvarez-González, 2007, Bou-Llusar et al., 2009).

\section{Control variable:}

The age of the companies has been introduced as a control variable, meaning the number of years from the creation of the firm.

\section{Results}

\subsection{Validity and reliability}

Partial Least Squares was employed to test the hypotheses, using SmartPLS 2.0. software. PLS is a regression-based structural equation modelling (SEM) technique that does not make assumptions about data distributions, employing a principal component-based estimation approach (Chin, 1998). PLS was chosen to carry out this research, since this methodology does not impose restrictions to the hypothesis model, simplifying the theory needed to work. Moreover, PLS tries to maximize the prediction power in the causal relations of the model. It 
allows flexible departure hypotheses as well as the sample size. To sum up, PLS has been employed for this study because of two principal reasons: first, the study is oriented to the prediction of dependant variables and, second, the sample size is not big (200 organizations). In this sense, Reinartz et al. (2009) affirms that PLS should be utilized when the number of observations is below 250 .

Several quality criteria studies were assessed (Table 2). Reliability of the measurement scales was verified with Cronbachs' Alpha coefficient, obtaining in all cases a value higher than 0.7. Composite reliability ranged between 0.92 and 0.96 , also exceeding threshold of 0.7 . An examination of the Average Variance Extracted (AVE) revealed that all constructs exceeded the 0.50 cut-off (Fornell and Larcker, 1981). Next, the discriminant validity of the measures was assessed. As Fornell and Larcker (1981) suggested, the AVE for each construct was greater than the squared latent factor correlations between pairs of constructs (see Table 2). Consequently, all variables exhibited satisfactory discriminant validity. In summary, the proposed model has good convergent validity, reliability and discriminant validity.

Table 2. Descriptive and correlations matrix.

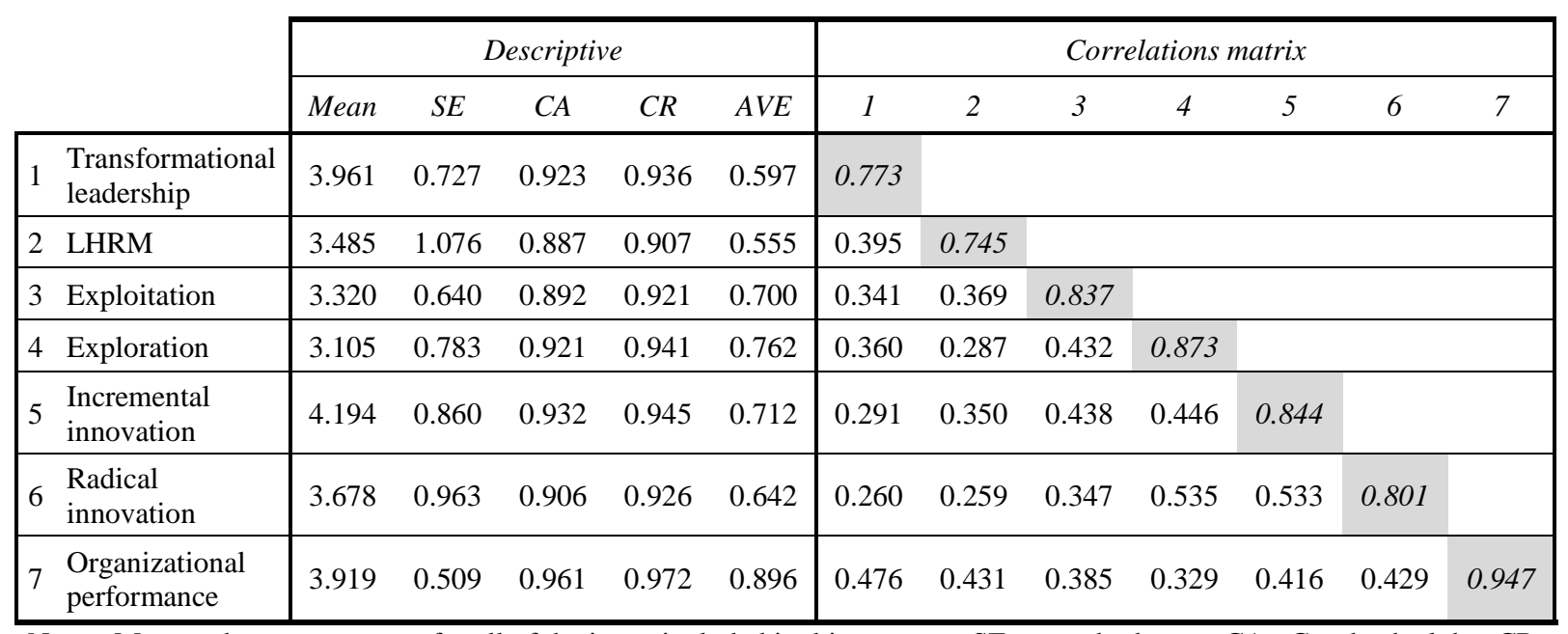

Notes: Mean $=$ the average score for all of the items included in this measure; $\mathrm{SE}=$ standard error; $\mathrm{CA}=\mathrm{Cronbach}$ alpha; $\mathrm{CR}$ $=$ composite reliability; AVE $=$ average variance extracted; N.A. = not applicable. The numbers in italics on the diagonal are the square root of the average variance extracted. Off-diagonal elements are correlations among constructs.

\subsection{Hypothesis testing}

To test the hypotheses, SmartPLS with the bootstrapping resampling method was used. PLS is insensitive to sample size considerations and handles both very small and very large 
samples more easily than does structural equation modelling (SEM). Furthermore, PLS handles both reflective and formative constructs (Hair et al., 2006).

A bootstrap resampling procedure with 5000 subsamples was developed (Chin, 1998) and, as shown in Table 3, the results illustrate that the direct hypothesized antecedents and consequences are largely confirmed (see figure 1).

Table 3. Construct structural model: Direct effects.

\begin{tabular}{|c|c|c|c|c|}
\hline Paths & $\begin{array}{c}\text { Standardised } \\
\text { coefficient }\end{array}$ & $\begin{array}{c}\text { Standard } \\
\text { Error }\end{array}$ & T Statistics & $R^{2}$ \\
\hline Transformational leadership $\rightarrow$ LHRM & $0.395^{* * *}$ & 0.077 & 5.154 & 0.156 \\
\hline LHRM $\rightarrow$ Exploitation & $0.369^{* * *}$ & 0.071 & 5.186 & 0.136 \\
\hline LHRM $\rightarrow$ Exploration & $0.287^{* * *}$ & 0.073 & 3.939 & 0.124 \\
\hline Exploitation $\rightarrow$ Incremental innovation & $0.438^{* * *}$ & 0.062 & 7.067 & 0.192 \\
\hline Exploration $\rightarrow$ Radical innovation & $0.535^{\text {*** }}$ & 0.061 & 8.785 & 0.286 \\
\hline Incremental innovation $\rightarrow$ Org. performance & $0.138^{*}$ & 0.071 & 1.946 & \multirow{4}{*}{0.384} \\
\hline Radical innovation $\rightarrow$ Org. performance & $0.224^{* * *}$ & 0.092 & 2.441 & \\
\hline Transformational leadership $\rightarrow$ Org. performance & $0.296^{* * *}$ & 0.083 & 3.587 & \\
\hline LHRM $\rightarrow$ Org. performance & $0.207^{* * *}$ & 0.067 & 3.095 & \\
\hline
\end{tabular}

Figure 1: Results of the hypotheses testing.

Testing for $\mathrm{H}_{1 \mathrm{a}}$ confirmed that the implementation of LHRM practices systems guidelines has a direct and positive effect on exploitation $(\beta=0.369, \mathrm{p}<.001)$. The results regarding this hypothesis confirm that the implementation the human resources policies help to exploit the organizational intrinsic skills, abilities and competences.

The hypothesis $\mathrm{H}_{1 \mathrm{~b}}$ is based on the relationship between a LHRM practices system and exploration. The results show a positive relationship $(\beta=0.287, \mathrm{p}<.001)$. In this case, the ability of an organization to enhance jointly selection, training, performance appraisal and compensation activities implies a major acquisition of new abilities, skills and competences for an organization.

The results regarding $\mathrm{H}_{2 \mathrm{a}}(\beta=0.438, \mathrm{p}<.001)$ display also a positive relationship, indicating that the ability of an organization to exploit its technology in its current innovative operations, as well as the ability to develop products based on experience and the capability to solve clients' problems with current solutions encourage innovative minor but continuous changes in products, processes and markets carried out by an organization. 
In hypothesis $\mathrm{H}_{2 \mathrm{~b}}$, the relationship between exploration and radical innovation was tested, being also positive. The results suggest a positive effect of exploration on radical innovation $(\beta=0.535, \mathrm{p}<.001)$, showing that the exploration of new knowledge facilitate the creation of new products, the utilization of new marketing channels and new opportunities in new markets are developed, as well as breakthrough changes in products, processes and services are encouraged.

Otherwise, the hypothesis $\mathrm{H}_{3 a}$ presents the results between incremental innovation and organizational performance, being, once again, positive $(\beta=0.138, p<0.05)$, demonstrating that improving frequently the existing products through existing knowledge, increasing scale economies in current markets and expanding services for current clients, among other aspects, enhance performance.

Regarding the hypothesis $\mathrm{H}_{3}$, a positive link exists between radical innovation and performance $(\beta=0.224, \mathrm{p}<0.01)$. This hypothesis manifests that producing new products or services by using new knowledge and abilities, searching new clients in new markets or experimenting with new products in new markets, among other aspects, provide superior productivity, benefits and profitability to firms, reducing also the unitary production cost of the products.

The positive direct effect of transformational leadership on results $(\beta=0.296, p<.001)$ was also confirmed, evincing the importance that this leadership style has in an organization as a key driver of the productivity, benefits, unitary production costs and profitability of a company. However, for testing the mediation effect of LHRM on the relationship between transformational leadership and organizational performance $\left(\mathrm{H}_{4}\right)$, PROCESS v2.16 software (Hayes, 2013) has been used. In this regard, Preacher and Hayes (2008) determine that the key condition for the analysis of the indirect effect consists of testing whether $\beta_{\text {Trans.Leadership } \rightarrow \text { LHRM }} \times \beta_{\text {LHRM } \rightarrow \text { Org.Performance }}$ is significant. As it is showed in table 4 , the indirect effect is significant $(\beta=0.111, \mathrm{p}<0.001)$. 
Table 4: Mediating effects.

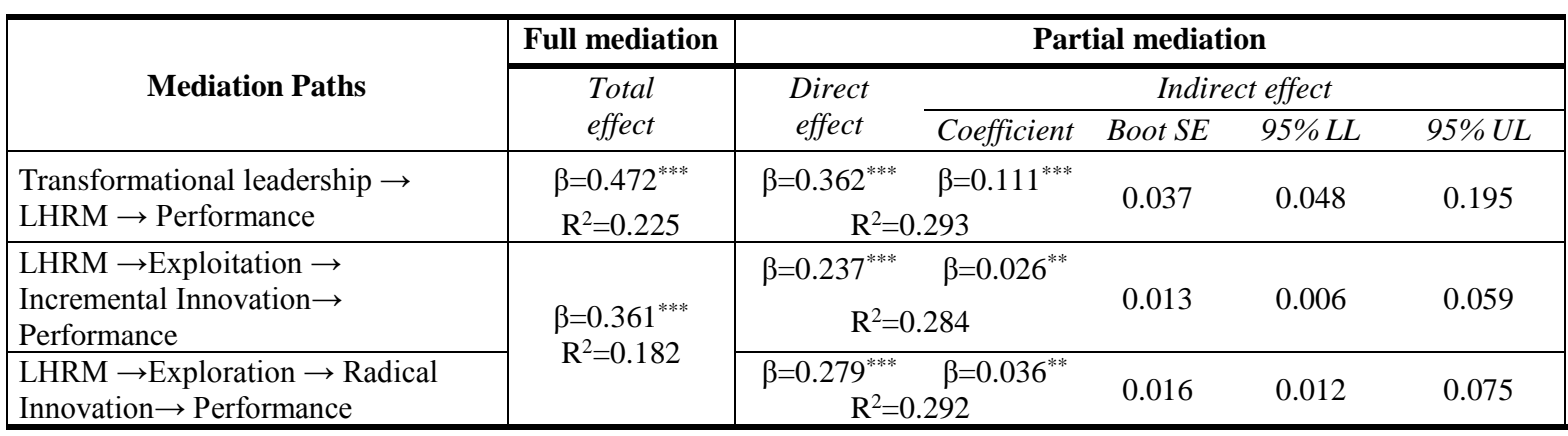

Note: $* * * \mathrm{p}<0.001 * * \mathrm{p}<0.01 * \mathrm{p}<0.05$; Bootstrapping based on $\mathrm{n}=5.000$ subsamples

Furthermore, for checking the mediation, we first analyse the effect of transformational leadership on performance without the mediation of LHRM $\left(\beta_{\text {total }}=0.472, p<0.001\right)$. Second, we analyse the existence of a partial mediation, studying the effect of both leadership $\left(\beta_{\text {direct }}=0.362, \mathrm{p}<0.001\right)$ and LHRM $\left(\beta_{\text {indirect }}=0.111, \mathrm{p}<0.001\right)$ on organizational performance. Since all these effects are significant and the explanation of the independence variable increases from $\mathrm{R}^{2}=0.225$ to $\mathrm{R}^{2}=0.293$ in the partial mediation model, we can assume that LHRM plays a partial mediating effect on the relationship between leadership on performance. Consequently, since transformational styles help to develop jointly systems of HR practices and develop knowledge in a firm, personnel management emerges abilities in employees. These abilities involve and inspire them, encourage the utilization of experienced knowledge and the acquisition of new one, enhance cooperation and collaboration through teamwork and motivate them, leading to increase performance. In this sense, leaders should enhance, among others, selection based on technical and problem-solving abilities, training based in quality principles and oriented to polyvalence, performance appraisals utilized for the development of employees or salary incentives fixed according to team performance.

Also, additional analyses help to analyse the effect of LHRM on performance, testing for the mediation role of learning and innovation. As it is showed in table 4, LHRM influences directly organizational performance $\left(\beta_{\text {total }}=0.361, \mathrm{p}<0.001 ; \mathrm{R}^{2}=0.18\right)$. Also, there is evidence about the double mediation of learning and innovation in these relationships. On the one 
hand, in the mediation model, both LHRM $\left(\beta_{\text {direct }}=0.237, \mathrm{p}<0.001\right)$ and exploitation learning * incremental innovation $\left(\beta_{\text {indirect }}=0.026, \mathrm{p}<0.01\right)$ explain organizational performance. On the other hand, also LHRM $\left(\beta_{\text {direct }}=0.279, \mathrm{p}<0.001\right)$ and exploration learning $*$ radical innovation $\left(\beta_{\text {indirect }}=0.036, \mathrm{p}<0.01\right)$ describe organizational performance. Both results confirm the existence of partial mediations of learning and innovation in the relationship between LHRM and performance, what supports literature arguments (Donate and Sánchez de Pablo, 2015). That means that jointly carried our HRM practices of selection, training, performance appraisal and compensation, led by transformational leaders, encourage innovative behaviours through the foundation of organizational knowledge. Besides, the methods and mechanisms that convert exploitation into performance are likely configured through continuous improvement and through the development and support to new technologies and abilities in processes (Alpkan et al., 2012).

\section{Discussion, conclusions and future research}

Organizations have a need of transformational leadership to improve performance. The results of this research are related to how performance can be increased by giving organizational learning and innovation a strategic role (Calantone et al., 2002). As commented in the Introduction section, many studies had analysed empirically the relationship between transformational leadership and organizational performance (Menguc et $a l .$, 2007), being also many the ones that ask for empirical studies that could examine the mediating terms in this relationship (García-Morales et al., 2008). This study has investigated a mediating mechanism of HRM, learning and innovation in the relationship between transformational leadership and organizational performance. While existent research has offered useful marks concerning the use of transformational leadership and the jointly application of several human resources practices in companies (Gillet and Vandenberghe, 2014), little empirical research has investigated their influence on learning and innovation (García-Morales et al., 2008, García-Morales et al., 2012). In this sense, the results support the importance of transformational leadership to develop a way to acquire abilities and 
competences that generate competitive advantages through innovation (García-Morales et al., 2012), defining this leadership as more committed to teamwork decisions and creator of capabilities. Innovative organizations learn to maintain themselves as competent, changing their behaviour through technology and production, promoting continuous improvement (Collins, 1999, García-Morales et al., 2012).

Moreover, transformational leaders help to implement jointly systems of HRM practices. This system should be based on a variety of selection methods, a great amount of training and training in quality techniques, performance appraisals made frequently and compensation founded on team performance, as well as salaries increases and promotions built on the effort and work of each employee and not in their job positions. When current knowledge about products and technologies are fostered, as well as abilities concerning the acquisition of new technologies, improvement of existing products and new products development, organizational performance is encouraged.

This is due to the fact that the HRM system helps to develop more available knowledge in an organization (Jaw and Liu, 2003) what, in turn, may lead to find better solutions to problems. More exploitation and exploration knowledge makes more difficult to competitors to imitate the work procedures and the solutions carried out, what may contribute to improvements in firm performance. Another contribution of this study is the fact that transformational managers also helps to improve organizational performance by exploiting their technology, their knowledge about their products and technology, by solving clients' problems with solutions extracted from past experience, through the development of products based on their experience and by improving their efficiency in the existing innovation activities. These activities allow organizations to substitute inefficient practices, to promote knowledge inside them and to transfer and enhance the use of best practices, leading to a more effective performance. Not only through these activities, but also by transferring new knowledge to the market, by creating new technologies and by trying to take advantage of new opportunities in new markets. In fact, to develop new production abilities, managerial 
abilities (e.g. market tendencies, project management, etc.) or new abilities in the area of new technologies, are key to deploy employees' abilities and exploit their knowledge, what requires of transformational styles of leadership. The same occurs with the completely deployment of new products for the industry and the reinforcement of the innovation abilities in areas where experience already existed.

These are the two pillars of organizational learning, what makes organizations to achieve improvements and transform the organization in a core of continuous improvement. Both transformational leadership and organizational learning are key processes in generating innovation for firms (Aragón-Correa et al., 2007), due to the fact that the processes of problem-solving, decisions-taking and continuous improvements developed in them, boost them to adaptation to changes and enhance innovative behaviours in order to improve performance.

This research has several implications for managers and scientists. Concretely, first, support has been found for the hypothesis that transformational leadership contributes positively to business performance, through the mediation of a LHRM practices system, exploration and exploitation, incremental and radical innovation. This means that organizations should promote the existence and development of transformational managers. These leaders must listen actively to persons, recognize their efforts, guarantee needed support for changes and communicate what could affect employees. Moreover, they must be involved in improvement activities, measure and review improvement in processes, stimulate cooperation among members and strive to meet clients' and society's needs.

Second, transformational leaders must promote LHRM practices that lead finally to enhance productivity, benefits, profitability and reduce unitary production cost. This last link is being a focus of increasing research in the last few years (Heffernan et al., 2016). Concretely, by embodying this system of HR practices, employees receive a considerable quantity of training, the contribution of employees is valued more than the position they occupy, salaries are fixed taking into account team performance or formal performance appraisals are 
developed, among other activities. All those promote organizational learning, embracing exploitation and exploration processes, since organizations should favour the acquisition, development and utilization of knowledge based on experience and of new knowledge. However, the need for more research to determine specifically which human resources practices are more linked to exploration and exploitation is addressed.

Third and, in this regard, leaders should try to make learning a key and focused aspect of the organization by investing in it, e.g., through the deployment of products based on existing experience and the exploitation of the technology of an organization in its current innovative operations, the learning of abilities and processes to develop products completely new for the industry or the acquisition of new management abilities (e.g. projects management, etc.) for innovation. That is, organizations must analyse their technology and production resources, trying to develop competences and capabilities that allow them to be more dynamic and competitive in today's environment, by creating competences that are unique, difficult to imitate or replicate and valuable. In this sense, leaders should be capable of guide employees in these processes, being accessible and answering to the questions and doubts personnel could have. Leaders should know how to make others learn and motivate them (MacKenzie et al., 2001, Hitt et al., 2005, Hanks, 2012).

Fourth, organizations that improve existing products and develop new ones, implant little adaptations for current products, expand services for current clients, experiment with new products in the local market, search new clients in new markets and so on, could give rise to a superior incremental and radical innovation, making emphasis in the fact that the more innovative the products or services are, the higher level of learning is requested. In this sense, leaders can do much work, taking into account that innovation is a result of teamwork, thanks to the creation of an environment of innovative behaviour and collaboration, investment in resources and support to new technologies and abilities in processes, promoting a culture that reward innovation (Senge et al., 1994). Consequently, organizational learning and innovation should be together stimulated creating synergies that may have an impact in the organization 
by improving results related to productivity, profitability, benefits and unitary production costs.

Some limitations of this study should be taken into account while analysing these findings. The most important limitation is the cross-sectional design of this research. Even though partial least squares was employed, interpretation of the causality between constructs should be accepted with caution (Tippins and Sohi, 2003). A longitudinal study in future will provide better results regarding causality.

Furthermore, the scales employed in the survey are measured from the managers' point of view and should be complemented with objective data. Besides, single informants were used as the information source for the questions related to learning competences, innovation and the LHRM system. Multiple informants would improve the validity of the results.

For future research, several approaches that could enrich the study of the analysed relationships may be identified. First, future research should analyse the type of organizational culture required to foster the relationships among transformational leadership, HR practices, learning knowledge, innovation and performance. Second, future research should study if there are more LHRM practices that may enhance exploitation and exploration, apart from the ones considered by this research. Moreover, other terms could be considered in the final effect of the analysed concepts in organizational performance. For example, future researchers are encouraged to measure, apart from firm performance, the level of employees' satisfaction, quality improvement or motivation and employees' commitment, when a transformational leadership style is developed in an organization. Finally, although selected variables in this research explain an important part of changes in organizational performance, other constructs could be examined, such as the level of technology, teamwork or employee's empowerment (Lloréns Montes et al., 2005, Vermeeren et al., 2014). 


\section{ITEM}

Mean

Standard

Deviation

1.- Items conducted to measure transformational leadership:

Regarding the managers of your company...

- They are actively involved in the improvement activities.

4,511

0,590

- The cooperation among members in the organization is stimulated.

- The structure of the organization is proportionated to support the implantation of the policy and strategy.

3,663

0,622

- They are interested in the measurement, review and improvement of processes' results.

$3,845 \quad 0,626$

$4,740 \quad 0,416$

- They strive to meet customers' needs.

- They are accessible, listen actively and answer the persons that integrate the organization.

- They recognize the efforts of persons and teams of all organizational levels.

- They guarantee the investment, the resources and the needed support for changes.

$3,863 \quad 0,660$

- They communicate changes and reasons that have caused them to employees and other stakeholders that may be affected by them.

$3,773 \quad 0,688$

2.- Items conducted to measure LHRM practices system:

In your company...

- $\quad$ Different selection methods are used to select the best candidate.

- Selection is based on technical abilities and capability to solve problems.

- Selection is oriented to identify abilities related to quality improvement.

- A considerable quantity of training is provided.

- Training is oriented to procure a variety of competences and polyvalence.

- $\quad$ Training is based in quality principles and tools and problems' solve.

- Performance appraisals are used to the improvement and development of

- Performance appraisals are based in the group or organization performance.

- To fixate compensation, it is more valued the contribution of the employee that the position that occupies.

- Salary increases are based in the personal development and training of

- $\quad$ Salary incentives are fixed according to teamwork performance.

2,365

3.- Items conducted to measure exploitation:

In the last three years, in which degree your organization has improved...

- Its knowledge about its products and technologies?.

- Its ability to exploit its technology in its current innovative operations?.

- Its capability to solve problems of its clients with solutions non very

- Its ability to develop products from which enough experience was already disposed?.

- Its efficiency in the existing innovative activities?.

4.- Items conducted to measure exploration:

In the last three years, in which degree your organization has...

- Acquired technologies and production abilities completely new for the organization?.

- Learnt abilities and processes of development of products completely new for the industry?.

- Acquired new management and organizational abilities (market tendencies, projects management, ...) that are important for innovation?.

- $\quad$ Acquired new abilities in areas such as support to new technologies?. 
- Reinforced the innovation abilities in areas where any experience existed?.

5.- Items conducted to incremental innovation:

In the last three years, your organization...

- Improve frequently the existing products.

$4,490 \quad 0,874$

- Implants regularly little adaptations to the existing products.

$4,260 \quad 0,909$

- Introduce improvements in its current products for the local market.

$4,100 \quad 0,880$

- Improve efficiency of its current products.

$4,175 \quad 0,841$

- Scale economies in current markets are increased.

4,025 $\quad 0,835$

- $\quad$ Services for current clients are expanded.

$4,200 \quad 0,777$

- The internal processes' costs reduction is considered as an important

4,110

0,831

6.- Items conducted to measure radical innovation:

In the last three years, in your organization...

- Demands that go more over current products are accepted.

- New products are invented.

- It is experimented with new products in our local market.

- It is commercialized with products that are completely new for our unit.

- New opportunities in new markets are frequently utilized.

- New marketing channels are regularly used.

- New clients in new markets are often searched.

7.- Items conducted to measure organizational performance:

Designate how the following indicators have evolved in the last three years in your company:

- The productivity of our organization.

- The unitary production cost of our products.

- The benefits of our organization. 


\section{References}

Abdul-Halim, H., Che-Ha, N., Geare, A. and Ramayah, T. (2016), "The pursuit of HR outsourcing in an emerging economy: The effects of HRM strategy on HR labour costs", Canadian Journal of Administrative Sciences / Revue Canadienne des Sciences de l'Administration, Vol. 33 No. 2, pp. 153-168.

Afacan Fındıklı, M., Yozgat, U. and Rofcanin, Y. (2015), "Examining Organizational Innovation and Knowledge Management Capacity The Central Role of Strategic Human Resources Practices (SHRPs)", Procedia - Social and Behavioral Sciences, Vol. 181 No. pp. 377-387.

Ahmad, M. and Allen, M. (2015), "High performance HRM and establishment performance in Pakistan: an empirical analysis", Employee Relations, Vol. 37 No. 5, pp. 506-524.

Ahmad, S. and Schroeder, R. G. (2002), "The importance of recruitment and selection process for sustainability of total quality management", International Journal of Quality \& Reliability Management, Vol. 19 No. 5, pp. 540-555.

Alpkan, L. Ü., Şanal, M. and Ayden, Y. Ü. (2012), "Market Orientation, Ambidexterity and Performance Outcomes", Procedia - Social and Behavioral Sciences, Vol. 41 No. 1, pp. 461468.

Andriopoulos, C. and Lewis, M. W. (2010), "Managing innovation paradoxes: Ambidexterity lessons from leading product design companies", Long Range Planning, Vol. 43 No. 1, pp. 104-122.

Aragón-Correa, J. A., García-Morales, V. J. and Cordón-Pozo, E. (2007), "Leadership and organizational learning's role on innovation and performance: Lessons from Spain", Industrial Marketing Management, Vol. 36 No. 3, pp. 349-359.

Arnold, T. J., Fang, E. and Palmatier, R. W. (2011), "The effects of customer acquisition and retention orientations on a firm's radical and incremental innovation performance", Journal of the Academy of Marketing Science, Vol. 39 No. 2, pp. 234-251.

Baker, W. E., Sinkula, J. M., Grinstein, A. and Rosenzweig, S. (2014), "The effect of radical innovation in/congruence on new product performance", Industrial Marketing Management, Vol. 43 No. 8, pp. 1314-1323.

Barba-Aragón, M. I., Jiménez-Jiménez, D. and Sanz-Valle, R. (2014), "Training and performance: The mediating role of organizational learning", BRQ Business Research Quarterly, Vol. 17 No. 3, pp. 161-173.

Bass, B. M. and Avolio, B. J. (2000), MLQ: Multifactor leadership questionnaire technical report, Sage Publications, Thousand Oaks.

Bass, B. M. and Steidlmeier, P. (1999), "Ethics, character, and authentic transformational leadership behavior", The Leadership Quarterly, Vol. 10 No. 2, pp. 181-217.

Bou-Llusar, J. C., Escrig-Tena, A. B., Roca-Puig, V. and Beltrán-Martín, I. (2009), "An empirical assessment of the EFQM Excellence Model: Evaluation as a TQM framework relative to the MBNQA Model", Journal of Operations Management, Vol. 27 No. 1, pp. 1-22.

Bowen, D. E. and Ostroff, C. (2004), "Understanding HRM-firm performance linkages: The role of the "strength" of the HRM system", Academy of management review, Vol. 29 No. 2, pp. 203-221.

Calantone, R. J., Tamer Cavusgil, S. and Zhao, Y. (2002), "Learning orientation, firm innovation capability, and firm performance", Industrial Marketing Management, Vol. 31 No. 1, pp. 515524.

Calvo-Mora, A., Ruiz-Moreno, C., Picón-Berjoyo, A. and Cauzo-Bottala, L. (2014), "Mediation effect of TQM technical factors in excellence management systems", Journal of Business Research, Vol. 67 No. 5, pp. 769-774.

Cingöz, A. and Akdoğan, A. A. (2013), "Strategic Flexibility, Environmental Dynamism, and Innovation Performance: An Empirical Study", Procedia - Social and Behavioral Sciences, Vol. 99 No. 0 , pp. 582-589.

Collins, L. K. (1999), An investigative study of the roles of incremental improvement (TQM) and radical innovation in organisational change strategies. C800958 Ph.D., Queen's University of Belfast (United Kingdom).

Chin, W. W. (1998), The Partial Least Squares Approach to Structural Equation Modeling, Lawrence 
Erlbaum Associates, Mahwah, NJ.

D'este, P., Rentocchini, F. and Vega-Jurado, J. (2014), "The role of human capital in lowering the barriers to engaging in innovation: evidence from the Spanish innovation survey", Industry and Innovation, Vol. 21 No. 1, pp. 1-19.

Donate, M. J. and Sánchez De Pablo, J. D. (2015), "The role of knowledge-oriented leadership in knowledge management practices and innovation", Journal of Business Research, Vol. 68 No. 2, pp. 360-370.

Efqm. (2013), "EFQM model for business excellence" [Online], available at: http://www.efqm.org (Accessed 5 May 2016).

Eskildsen, J. K. (1998), "Identifying the vital few using the European Foundation for Quality Management Model", Total Quality Management, Vol. 9 No. 4/5, pp. S92-S95.

Felstead, A., Gallie, D., Green, F. and Zhou, Y. (2010), "Employee involvement, the quality of training and the learning environment: an individual level analysis", The International Journal of Human Resource Management, Vol. 21 No. 10, pp. 1667-1688.

Fornell, C. and Larcker, D. F. (1981), "Evaluating structural equation models with unobservable variables and measurement error", Journal of Marketing Research, Vol. XXVII No. February, pp. 39-50.

García-Morales, V. J., Jiménez-Barrionuevo, M. M. and Gutiérrez-Gutiérrez, L. (2012), "Transformational leadership influence on organizational performance through organizational learning and innovation", Journal of Business Research, Vol. 65 No. 7, pp. 1040-1050.

García-Morales, V. J., Lloréns-Montes, F. J. and Verdú-Jover, A. J. (2008), "The Effects of Transformational Leadership on Organizational Performance through Knowledge and Innovation", British Journal of Management, Vol. 19 No. 4, pp. 299-319.

García-Morales, V. J., Matías-Reche, F. and Hurtado-Torres, N. (2008), "Influence of transformational leadership on organizational innovation and performance depending on the level of organizational learning in the pharmaceutical sector", Journal of Organizational Change Management, Vol. 21 No. 2, pp. 188-212.

Gillet, N. and Vandenberghe, C. (2014), "Transformational Leadership and Organizational Commitment: The Mediating Role of Job Characteristics", Human Resource Development Quarterly, Vol. 25 No. 3, pp. 321-347.

Goldman, E., Wesner, M. and Karnchanomai, O. (2013), "Reciprocal peer coaching: A critical contributor to implementing individual leadership plans", Human Resource Development Quarterly, Vol. 24 No. 1, pp. 63-87.

Gumusluoglu, L. and Ilsev, A. (2009), "Transformational leadership, creativity, and organizational innovation", Journal of Business Research, Vol. 62 No. 4, pp. 461-473.

Hair, J. F., Anderson, R. L. and Tatham, W. C. (2006), Multivariate data analysis, Pearson, Upper Saddle River, NJ.

Hallinger, P. (2003), "Leading Educational Change: reflections on the practice of instructional and transformational leadership", Cambridge Journal of Education, Vol. 33 No. 3, pp. 329-352.

Hanks, S. H. (2012), "Leadership Potential, Leadership Discretion Recent Academic Research on People and Strategy", People \& Strategy Vol. 35 No. 3, pp. 10-11.

Hayes, A. F. (2013), Introduction to mediation, moderation and conditional process analysis, The Guilford Press, New York.

Heffernan, M., Harney, B., Cafferkey, K. and Dundon, T. (2016), "Exploring the HRM-performance relationship: the role of creativity climate and strategy", Employee Relations, Vol. 38 No. 3, pp. 438-462.

Hitt, M. A., Ireland, R. D. and Rowe, G. W. (2005), Handbook on Responsible Leadership and Governance in Global Business, Edward Elgar Publishing Limited, Great Britain.

Hoon Song, J., Kolb, J. A., Hee Lee, U. and Kyoung Kim, H. (2012), "Role of transformational leadership in effective organizational knowledge creation practices: Mediating effects of employees' work engagement", Human Resource Development Quarterly, Vol. 23 No. 1, pp. 65-101.

Hung, R. Y. Y., Lien, B. Y.-H., Yang, B., Wu, C.-M. and Kuo, Y.-M. (2011), "Impact of TQM and organizational learning on innovation performance in the high-tech industry", International Business Review, Vol. 20 No. 2, pp. 213-225. 
Huselid, M. A. (1995), "The Impact of Human Resource Management Practices on Turnover, Productivity, and Corporate Financial Performance", Academy of Management Journal, Vol. 38 No. 3, pp. 635.

Jansen, J. J. P., Bosch, F. and Volberda, H. W. (2006), "Exploratory innovation, exploitative innovation, and performance: effects of organizational antecedents and environmental moderators", Management Science, Vol. 52 No. 11, pp. 1661-1674.

Jaw, B. S. and Liu, W. (2003), "Promoting organizational learning and self-renewal in Taiwanese companies: the role of HRM", Human Resource Management, Vol. 42 No. 3, pp. 223-241.

Jiménez-Jiménez, D. and Sanz-Valle, R. (2011), "Innovation, organizational learning, and performance", Journal of Business Research, Vol. 64 No. 4, pp. 408-417.

Jung, D. I. and Sosik, J. J. (2002), "Transformational leadership in work groups: The role of empowerment, cohesiveness, and collective-efficacy on perceived group performance", Small group research, Vol. 33 No. 3, pp. 313-336.

Kyriakopoulos, K. and Moorman, C. (2004), "Tradeoffs in marketing exploitation and exploration strategies: The overlooked role of market orientation", International Journal of Research in Marketing, Vol. 21 No. pp. 219-240.

Lertxundi, A. and Landeta, J. (2011), "The moderating effect of cultural context in the relation between HPWS and performance: An exploratory study in Spanish multinational companies", The International Journal of Human Resource Management, Vol. 22 No. 18, pp. 3949-3967.

Lu, T.-T. and Chen, J.-C. (2010), "Incremental or radical? A study of organizational innovation: An artificial world approach", Expert Systems with Applications, Vol. 37 No. 12, pp. 8193-8200.

Luca, L. M. D. and Atuahene-Gima, K. (2007), "Market knowledge dimensions and cross-functional collaboration: Examining the different routes to product innovation performance", Journal of Marketing, Vol. 71 No. 1, pp. 95-112.

Lloréns Montes, F. J., Ruiz Moreno, A. and García Morales, V. (2005), "Influence of support leadership and teamwork cohesion on organizational learning, innovation and performance: an empirical examination", Technovation, Vol. 25 No. 10, pp. 1159-1172.

Mackenzie, S. B., Podsakoff, P. M. and Rich, G. A. (2001), "Transformational and Transactional Leadership and Salesperson Performance", Journal of the Academy of Marketing Science, Vol. 29 No. 2, pp. 115-134.

March, J. G. (1991), "Exploration and exploitation in organizational learning", Organizational Science, Vol. 2 No. 1, pp. 71-87.

Mckinley, W., Latham, S. and Braun, M. (2014), "Organizational decline and innovation: Turnarounds and downward spirals", Academy of Management Review, Vol. 39 No. 1, pp. 88-110.

Menguc, B., Auh, S. and Shih, E. (2007), "Transformational leadership and market orientation: Implications for the implementation of competitive strategies and business unit performance", Journal of Business Research, Vol. 60 No. 4, pp. 314-321.

Murat Ar, I. and Baki, B. (2011), "Antecedents and performance impacts of product versus process innovation: Empirical evidence from SMEs located in Turkish science and technology parks", European Journal of Innovation Management, Vol. 14 No. 2, pp. 172-206.

Narver, J. C. and Slater, S. F. (1990), "The effect of a market orientation on business profitability", The Journal of Marketing, Vol. 54 No. 4, pp. 20-35.

Obeidat, S. M., Mitchell, R. and Bray, M. (2016), "The link between high performance work practices and organizational performance: Empirically validating the conceptualization of HPWP according to the AMO model", Employee Relations, Vol. 38 No. 4, pp. 578-595.

Po-Chien, C. and Shyh-Jer, C. (2011), "Crossing the level of employee's performance: HPWS, affective commitment, human capital, and employee job performance in professional service organizations", International Journal of Human Resource Management, Vol. 22 No. 4, pp. 883-901.

Pooja, M., Shreya, J. and Abhay, S. (2013), "Compensation: impact of rewards and organisational justice on turnover intentions and the role of motivation and job satisfaction: a study of retail store operations in NCR", International Journal of Human Resource Development and Management, Vol. 13 No. 2/3, pp. 136-152.

Popadiuk, S. (2012), "Scale for classifying organizations as explorers, exploiters or ambidextrous", International Journal of Information Management, Vol. 32 No. 1, pp. 75-87. 
Preacher, K. J. and Hayes, A. F. (2008), "Asymptotic and resampling strategies for assessing and comparing indirect effects in multiple mediator models", Behavior Research Methods, Vol. 40 No. 3, pp. 879-891.

Reinartz, W. J., Haenlein, M. and Henseler, J. (2009), "An empirical comparison of the efficacy of covariance-based and variance based SEM", International Journal of Market Research, Vol. 26 No. 4, pp. 332-344.

Santangelo, G. D. and Pini, P. (2011), "New HRM practices and exploitative innovation: A shopfloor level analysis", Industry and innovation, Vol. 18 No. 6, pp. 611-630.

Santos-Vijande, M. L. and Álvarez-González, L. I. (2007), "TQM and firms performance: An EFQM excellence model research based survey", Int. Journal of Business Science and Applied Management, Vol. 2 No. 2, pp. 21-41.

Senge, P., Roberts, C., Ross, R. B., Smith, B. J. and Kleiner, A. (1994), The fifth discipline fieldbook, Doubleday Publ., New York.

Senge, P. M. (1990), The fifth discipline: the art and practice of the learning organization, New YorkUSA.

Shahin, A., Barati, A., Dabestani, R. and Khalili, A. (2017), "Determining factors influencing radical and incremental innovation with a case study in the petrochemical industry", International Journal of Business Innovation and Research, Vol. 12 No. 1, pp. 62-79.

Soltani, E., Van Der Meer, R. B., Gennard, J. and Williams, T. N. (2003), A TQM approach to evaluation criteria for human resource performance: results of a questionnaire survey, Dept. of Management Science, University of Strathclyde, Glasgow.

Tippins, M. J. and Sohi, R. S. (2003), "IT competency and firm performance: Is organizational learning a missing link?", Strategic Management Journal, Vol. 24 No. 8, pp. 745-761.

Tontini, G. and Picolo, J. D. (2014), "Identifying the impact of incremental innovations on customer satisfaction using a fusion method between importance-performance analysis and Kano model", International Journal of Quality \& Reliability Management Vol. 31 No. 1, pp. 32-52.

Turner, N., Swart, J. and Maylor, H. (2013), "Mechanisms for managing ambidexterity: A review and research agenda", International Journal of Management Reviews, Vol. 15 No. 3, pp. 317-332.

Vermeeren, B., Kuipers, B. and Steijn, B. (2014), "Does leadership style make a difference? Linking HRM, job satisfaction, and organizational performance", Review of Public Personnel Administration, Vol. 34 No. 2, pp. 174-195.

Wallo, A., Kock, H. and Nilsson, P. (2016), "Setting the stage for innovation: towards a conceptual model of the HR-innovation link", International Journal of Human Resources Development and Management, Vol. 16 No. 1-2, pp. 100-120.

Wang, S. and Noe, R. A. (2010), "Knowledge sharing: A review and directions for future research", Human Resource Management Review, Vol. 20 No. 2, pp. 115-131. 
Figure 1: Results of the hypotheses testing.

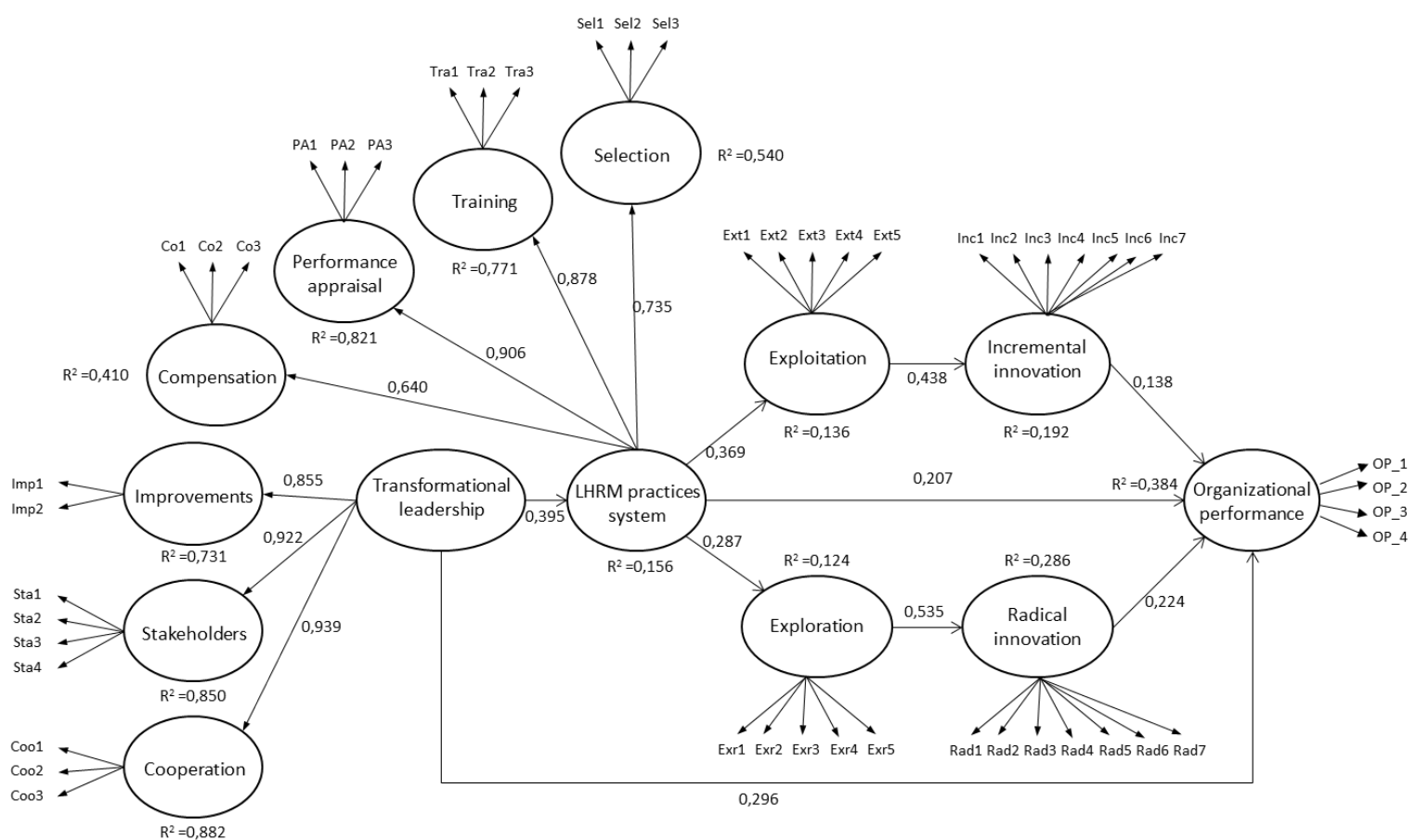

